\title{
Impact of anti-glutamic acid decarboxylase-65, anti-insulin and anti-tyrosine phosphatase autoantibodies on disease activity in type 1 diabetes patients
}

\author{
Jalees Farhan ${ }^{1}$, Abdullah Alghasham², Uzma Zafar ${ }^{3}$, Abdel-Raheim MA. Meki ${ }^{1}$ and Zafar Rasheed ${ }^{*}$ \\ *Correspondence: zafarrasheed@qumed.edu.sa \\ 'Department of Medical Biochemistry, College of Medicine, Qassim University, Buraidah, Saudi Arabia. \\ ${ }^{2}$ Department of Pharmacology and Therapeutics, College of Medicine, Qassim University, Buraidah, Saudi Arabia. \\ ${ }^{3}$ Department of Pathology, College of Medicine, Qassim University, Buraidah, Saudi Arabia.
}

\begin{abstract}
Background: Type 1 diabetes mellitus (T1D) is a chronic autoimmune disease with autoantibodies against glutamic-aciddecarboxylase (GAD)65, insulin and tyrosine phosphatase (TP) as a feature of disease. The correlations of these autoantibodies with disease severity remain to be explored. Here we investigate the status and contribution of autoantibodies against GAD65, insulin and TP in T1D patients and to explore whether these antibodies have a role in T1D progression and in T1D associated neuropathy.

Methods: Sera from 57 T1D patients with varying levels of disease activities and 42 age- and sex-matched healthy controls were evaluated for anti-GAD65-antibodies, anti-insulin-antibodies and anti-TP-antibodies.

Results: Serum analysis showed T1D patients contain 42\% of anti-GAD65-antibodies, $76 \%$ of anti-insulin-antibodies and 34\% of anti-TP-antibodies. Interestingly, not only was there an increased number of subjects positive for these antibodies, but also levels of these antibodies were significantly higher among T1D patients whose ages were $>35$ years as compared with younger T1D patients (age $\leq 35$ years). In addition, significant correlation was observed between the levels of these antibodies and glycosylated haemoglobin $\left(\mathrm{HbA}_{1 \mathrm{c}}\right)$. Furthermore, T1D neuropathic patients had higher levels of these antibodies compared with T1D patients without neuropathy.

Conclusions: Our data support an association between these markers autoantibodies and severity of T1D. The stronger response observed in patients with uncontrolled T1D suggests that these antibodies may be useful biomarkers in evaluating the progress of T1D and in elucidating the mechanisms of disease pathogenesis.
\end{abstract}

Keywords: Diabetes type 1, autoimmunity, anti-GAD65-autoantibodies, anti-insulin-autoantibodies, anti-TP-autoantibodies, T1D progress, T1D associated neuropathy

\section{Introduction}

Type 1 diabetes mellitus (T1D) is an autoimmune disease characterized by the targeted destruction of the insulinsecreting $\beta$-cells within the pancreatic islet [1]. The precise etiology remains uncertain; however, there is a general consensus that T1D is a T-cell mediated disorder that results from immune dysfunctions, with subsequent loss of tolerance to $\beta$ cell antigens and destructive lymphocytic infiltration of the islets. This, in turn, leads to hyperglycemia [2]. Although unlikely to be intrinsically diabetogenic, circulating autoantibodies targeting pancreatic $\beta$ cell proteins have been defined [3]. Monitoring such systemic autoantibodies is currently the most reliable biomarker in the prodromal phase of T1D, since their appearance typically precedes overt T1D onset for years $[1,2]$. This provides a window for therapeutic intervention, and considerable effort has been devoted for identification of autoantigens as biomarkers of T1D. In the absence of reliable T-cell tests, dissection of autoantibody responses in subjects of genetic risk should prove useful in identifying triggers of islet autoimmunity by examining seroconversion and maturation of the autoantibody response that may mark time to onset of T1D [4]. The complexity ofthe disease process is exemplified by multiple clinical phenotypes, including autoimmune diabetes masquerading as type 2 diabetes in youth and adults [5]. Autoantibodies may also provide prognostic information in clinically heterogeneous patient populations when examined longitudinally [6]. The ability to measure autoantibodies in type 1 diabetes using recombinant autoantigens has paved the way for the identification of several different autoantigens detected by autoantibodies in a large number of other autoimmune disorders butthe utility of these autoantigens is yet to be standardized [7]. Furthermore, the islet cell autoantibodies (ICA) reactivity does not always correlate toward defined autoantigens, suggests that additional specific autoantigens remain to be identified [8]. However, three major targets $\left(\mathrm{GAD}_{65}\right.$, insulin and IA-2) have been confirmed, with approximately $94 \%$ of all subjects with a clinical diagnosis of T1D expressing autoantibodies

(C) 2013 Rasheed et al; licensee Herbert Publications Ltd. This is an Open Access article distributed under the terms of Creative Commons Attribution License (http://creativecommons.org/licenses/by/3.0). This permits unrestricted use, distribution, and reproduction in any medium, provided the original work is properly cited. 
Farhan et al. Journal of Diabetes Research \& Clinical Metabolism 2013, http://www.hoajonline.com/journals/pdf/2050-0866-2-24.pdf

Table 1. Clinical characteristics of type 1 diabetes patients.

\begin{tabular}{lccc}
\hline Parameters & T1D patients & T1D neuropathy & Healthy controls \\
\hline & (mean \pm SD) & $($ mean \pm SD) & (mean \pm SD) \\
\hline $\mathrm{n}$ & 57 & 13 & 42 \\
Age (years) & $49 \pm 15^{*}$ & $42 \pm 13^{*}$ & $43 \pm 17$ \\
Sex (M/F) & $32 \mathrm{M} / 25 \mathrm{~F}$ & $8 \mathrm{M} / 5 \mathrm{~F}$ & $27 \mathrm{M} / 15 \mathrm{~F}$ \\
$\begin{array}{l}\text { Blood glucose } \\
(\mathrm{mg} / \mathrm{dl})\end{array}$ & $345 \pm 87^{*}$ & $352 \pm 34.3^{*}$ & $109 \pm 9$ \\
$\mathrm{HbA}_{1 \mathrm{C}}$ & $8.0 \pm 1.5^{\circledR}$ & $8.1 \pm 0.82^{\circledR}$ & $4.7 \pm 0.4$ \\
\hline
\end{tabular}

Abbreviations: T1D, type 1 diabetes mellitus; $n$, number of serum samples tested; HbA1C, glycosylated hemoglobin. ${ }^{*} \mathrm{p}>0.05$ versus age of healthy controls; $\# \mathrm{p}<0.001$ versus blood glucose of healthy controls; @p $<0.001$ versus HbA1C of healthy controls.

to at least one of these molecules at clinical onset [9-11].

Autonomic neuropathy is a severe and crippling complication of T1D of long duration; recent evidences indicate that immune pathogenesis plays an important role in this complication [12-15]. Lymphocytes and plasma cells infi-Itrate autonomic ganglia and nerve bundles [13], and in the circulation, activated T-cells [14] and complement breakdown products [15] are present at elevated levels. It is well reported that autoantibodies to nervous tissues were found in T1D neuropathic patients, but not in patients with T1D of similar duration but without complications [16-18]. The potential role of auto reactive T- and B-cells sensitized to nervous tissue components in the development of autonomic neuropathy is supported by a report of Kaufman et al., [19] describing autoantibodies to $\mathrm{GAD}_{65}$ in all the five diabetic patients with neuropathy in their study, but in none of the four patients with T1D of comparable duration and no complications. In contrast, many correspondences dispute this association [20-22].

In view of these inconclusive and controversial natures of these reports, the present study was designed to investigate the status and contribution of autoantibodies to $\mathrm{GAD}_{65}$, insulin and tyrosine phosphatase in T1D and to explore whether these autoantibodies have a role in disease progression and in T1D associated neuropathy.

\section{Methods}

\section{Human subjects}

Present study has been carried out in accordance with the Code of Ethics of the World Medical Association (Declaration of Helsinki) for human samples and has been approved by the local ethical committe. The study group included 57 patients ( 32 male and 25 female) with type 1 diabetes mellitus and the age range was $21-52$ years (mean \pm SD years $49 \pm 15$ years). The control group comprised 42 healthy subjects (27 male and 15 female), age range 18-48 years (mean $\pm S D$ years $43 \pm 17$ years). The mean ages were not significantly different between the groups ( $p>0.05$ ). The average $( \pm S D)$ of post prandial blood sugar level for
57 T1D was $345 \pm 87 \mathrm{mg} / \mathrm{dl}$, while for 42 healthy subjects it was $109 \pm 9 \mathrm{mg} / \mathrm{dl}$. The average $( \pm \mathrm{SD})$ glycosylated hemoglobin $\left(\mathrm{HbA}_{1 \mathrm{C}}\right)$ for patients was $8.0 \pm 1.5$, whereas for normal subjects it was $4.7 \pm 0.4$. Diabetic neuropathy was assessed by physical examination and nerve conduction studies. The clinical characteristics of the subjects recruited are summarized in Table 1. Venous blood from all studied subjects was collected, and sera were separated. All serum samples were heated in water bath at $56^{\circ} \mathrm{C}$ for $30 \mathrm{~min}$ to inactivate complement system and were stored in small aliquots at $-80^{\circ} \mathrm{C}$ until analysed further.

\section{Sandwich ELISAs}

Overproduction of anti-GAD 65 antibodies or anti-TP antibodies in T1D patients were determined by Sandwich enzyme-linked immunosorbent assays (ELISA) established in our laboratory. Briefly, flat bottomed 96 -well microtiter plates (polystyrene polysorp immunoplates, NuncImmunoTM MicroWell, Sigma) were coated with GAD-65/67 (C-20) polyclonal antibodies (catalog \# sc-7513, Santa Cruz Biotechnology, CA) or PRL-1/2/3 (C-14) antibodies (catalog \# sc-49253; Santa Cruz Biotechnology) overnight at $4^{\circ} \mathrm{C}$. The plates were washed with TBS-Tween 20 and the nonspecific binding sites were blocked with TBS containing $1 \%$ BSA (Sigma) at room temperature for $1 \mathrm{~h}$. After washing extensively with TBS-Tween $20,100 \mu$ l of patient's sera (1:100 diluted) were added to duplicate wells of the coated plate and incubated at room temperature for $2 \mathrm{~h}$ and overnight at $4^{\circ} \mathrm{C}$. The plates were washed five times with TBS-Tween 20 and $100 \mu$ lof GAD-65 (H-95) monoclonal IgG (catalog \# sc-5601, Santa Cruz Biotechnology; diluted 1:100) or PRL-1/2/3 (FL-173) antibodies (catalog \# sc-33197, Santa Cruz Biotechnology; diluted 1:100) were incubated at room temperature for $2 \mathrm{~h}$. The plates were washed extensively and $100 \mu \mathrm{l}$ of anti-human IgG-horseradish peroxidase (catalog \# sc2769, Santa Cruz Biotechnology) was added and incubated for $2 \mathrm{~h}$. After washing, $100 \mu \mathrm{l}$ of 3,3',5,5'-Tetramethylbenzidine peroxidase substrate (TMB, catalog \# 206697A, Santa Cruz Biotechnology) was added to each well. The reaction was stopped after 10 minutes by adding $100 \mu$ l of stop solution $\left(2 \mathrm{M} \mathrm{H}_{2} \mathrm{SO}_{4}\right.$ ) and OD was read at $405 \mathrm{~nm}$ on an automatic microplate reader (AnthosZenyth 3100 Multimode Detectors, Salzburg, Austria).

\section{Preparation of human insulin antigen for direct binding ELISA}

An aqueous solution of human insulin (code \# L1384-OL, Aventis Pharma Deutschland GmbH, Frankfurt, Germany) was diluted in phosphate buffer saline $(10 \mathrm{mM} ; 150 \mathrm{mM}$ $\mathrm{NaCl}$ ) and $\mathrm{pH}$ was adjusted to 7.4 using $6 \mathrm{~N} \mathrm{NaOH}$ (SigmaAldrich). This insulin solution was dialyzed extensively against PBS (150 mM NaCl, pH 7.4).

\section{Direct binding ELISA}

Anti-insulin autoantibodies were detected by Direct 
(a)

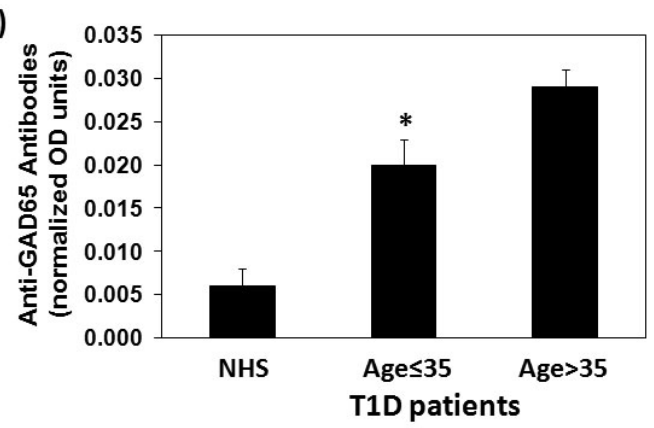

(b)

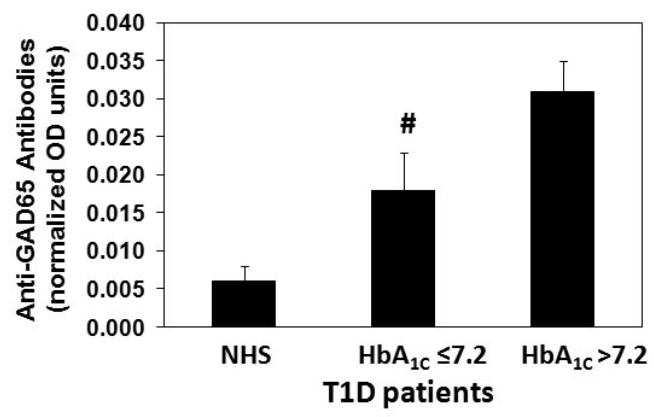

Figure 1. Detection of anti-glutamic acid decarboxylase 65 (GAD65) antibodies in type 1 diabetes patients.

(a) Age-wise detection of anti-GAD ${ }_{65}$ antibodies in type 1 diabetes (T1D) patients. ${ }^{*} \mathrm{p}<0.001$ versus anti$\mathrm{GAD}_{65}$ antibodies detected in T1D patients of age $>35$; ${ }^{*} \mathrm{p}<0.0001$ versus anti- $\mathrm{GAD}_{65}$ antibodies detected in normal human subjects (NHS).

(b) Glycosylated hemoglobin (HbA1C)-wise detection of anti-GAD ${ }_{65}$ antibodies in T1D patients. \#p $<0.001$ versus anti- $\mathrm{GAD}_{65}$ antibodies detected in T1D patients withHbA5 $1 \mathrm{C}>7.2$; $\# \mathrm{p}<0.0001$ versus anti$\mathrm{GAD}_{65}$ antibodies detected in NHS. Thenumber of T1D serum samples was 57 and NHS was $42 . \mathrm{GAD}_{65}{ }^{-}$ specific sandwich ELISAs were used and serum samples were 1:100 diluted. Results show mean with 95\% CI.

binding ELISA. It was performed on flat bottom 96-well, polystyrene maxiSorp immunoplates (Catalog \# P8616; Nunc-ImmunoTM MicroWell, Sigma-Aldrich) as described previously by our published procedure [22]. Briefly, polystyrene maxisorp immunoplates were coated with $100 \mu \mathrm{l}$ of insulin antigen $(10 \mu \mathrm{g} / \mathrm{ml})$ in carbonate buffer (0.05 M, pH 9.6). The plates were coated for $2 \mathrm{~h}$ at room temperature (RT) and overnight at $4^{\circ} \mathrm{C}$. Each sample was coated in duplicate and half of the plates served as control devoid of only antigen coating. Unbound antigen was washed with PBS-T $(10 \mathrm{mM}, 150 \mathrm{mMNaCl}, \mathrm{pH}$ 7.4 containing $0.05 \%$ Tween-20) and unoccupied sites were blocked with block buffer (PBS containing 1\% BSA) for 1-2 $h$ at RT. After incubation, the plates were washed with PBS-T. The test serum (1:100) in PBS-T (100 $\mu \mathrm{l} /$ well) was adsorbed for $2 \mathrm{~h}$ at RT and overnight at $4^{\circ} \mathrm{C}$. Bound antibodies were analysed with anti-human HRP linked conjugate (catalog \# sc2769, Santa Cruz Biotechnology) using 3,3',5,5'-Tetramethylbenzidine substrate (TMB, catalog \# 206697A, Santa Cruz Biotechnology). Reaction was stopped by stop solution $\left(2 \mathrm{M} \mathrm{H}_{2} \mathrm{SO}_{4}\right)$ and absorbance of each well was recorded at $405 \mathrm{~nm}$ on an automatic microplate reader (Anthos Zenyth 3100 Multimode Detectors, Salzburg, Austria).

\section{Statistical analysis}

All measurements were performed in duplicates using ageand sex-matched diabetes or control samples. Comparisons were performed using Origin 6.1 software package (Northampton, MA, USA) and Graph Pad Prism-5 (San Diego, CA, USA) (one paired two tailed t-test with ANOVA analysis and Tukey's post-hoc analysis). $P$ values less than 0.05 were considered significant, and $P$ values less than 0.001 were considered highly significant. Values shown as mean \pm SEM ( $95 \%$ confidence level) unless stated otherwise.

\section{Results}

Recognition of $\mathrm{GAD}_{65}$ by Type 1 diabetes autoantibodies In an attempt to find out the role of $\mathrm{GAD}_{65}$ in pathogenesis of type 1 diabetes (T1D), this report determines the serum levels of $\mathrm{GAD}_{65}$ specific antibodies in patients with T1D. Sera from 57 T1D patients and 42 normal human (NH) subjects were tested for the detection of anti-GAD ${ }_{65}$ autoantibodies by $\mathrm{GAD}_{65}$-specific sandwich ELISAs. Data showed thatT1D patient's serum autoantibodies showed strong binding to $G A D_{65}$ at 1:100 serum dilutions. To validate our hypothesis, we assessed the increases in serum levels of anti-GAD ${ }_{65}$ antibodies as a function of the disease progress (Figure 1). As evident in Figure 1a, levels of anti-GAD ${ }_{65}$ antibodies in all of the diabetes patients (both those with age $\leq 35$ years and those with age $>35$ ) were significantly higher in comparison with healthy controls $(p<0.0001)$. Interestingly, levels of anti-GAD ${ }_{65}$ antibodies in diabetes patients with age $>35$ years were significantly higher than those age $\leq 35$ years $(p<0.001)$. To further investigate the relation of T1D patient's age and the occurrence of autoantibodies, T1D patients were divided into different age groups in accordance with the guidelines on age-wise distribution of diabetes and pre-diabetes $[\mathbf{2 3}, \mathbf{2 4}]$. Our data showed that autoantibodies against $\mathrm{GAD}_{65}$ increase with the patient's age (Table 2). In addition, remarkably increase in levels of anti$\mathrm{GAD}_{65}$ antibodies in patients with higher $\mathrm{HbA}_{1 \mathrm{C}}$ (Figure 1b) in comparison with those in patients with lower $\mathrm{HbA}_{1{ }^{\prime}}$ suggesting a positive association between the increase in anti-GAD ${ }_{65}$ antibodies and $\mathrm{HbA}_{1 C}$ levels. Not only this, our data also showed that levels of anti-GAD ${ }_{65}$ antibodies were significantly higher in those diabetic neuropathy patients as compared to those T1D patients who were not associated with neuropathy (Table 3). 
Farhan et al. Journal of Diabetes Research \& Clinical Metabolism 2013, http://www.hoajonline.com/journals/pdf/2050-0866-2-24.pdf

Table 2. Age wise distribution of serum autoantibodies in type 1 diabetes patients.

\begin{tabular}{lcccc}
\hline Age years & $\mathbf{n}$ & $\begin{array}{c}\text { Anti-GAD65 antibodies } \\
\text { (normalized OD units) }\end{array}$ & $\begin{array}{c}\text { Anti-insulin antibodies } \\
\text { (normalized OD units) }\end{array}$ & $\begin{array}{c}\text { Anti-TP antibodies } \\
\text { (normalized OD units) }\end{array}$ \\
\hline $10-20$ & 07 & 0.014 & 0.021 & 0.007 \\
$21-30$ & 05 & 0.018 & 0.033 & 0.011 \\
$31-40$ & 23 & 0.021 & 0.039 & 0.013 \\
$41-50$ & 11 & 0.025 & 0.048 & 0.015 \\
$51-60$ & 07 & 0.031 & 0.059 & 0.019 \\
$>61$ & 04 & 0.032 & 0.053 & 0.018 \\
$49 \pm 15$ & 57 & $0.024 \pm 0.007$ & $0.042 \pm 0.014$ & $0.014 \pm 0.005$ \\
$($ mean \pm SD) & (TS) & $($ mean \pm SEM) & $($ mean \pm SEM) & $($ mean \pm SEM $)$ \\
\hline
\end{tabular}

Abbreviations: GAD65, glutamic acid decarboxylase; TP, tyrosine phosphate; $n$, number of samples tested, SD, standard error; SEM, standard error of mean; TS, total number of samples.

Table 3. Levels of anti-GAD ${ }_{65}$ antibodies, anti-insulin antibodies and anti-TP antibodies in patients with type 1 diabetes and diabetic neuropathy.

\begin{tabular}{lccc}
\hline Parameters & $\begin{array}{c}\text { T1D } \\
\text { (mean } \pm \text { SEM) }\end{array}$ & $\begin{array}{c}\text { T1D neuropathy } \\
\text { (mean } \pm \text { SEM) }\end{array}$ & $\begin{array}{c}\text { Healthy controls } \\
(\text { mean } \pm \text { SEM) }\end{array}$ \\
\hline $\mathrm{n}$ & 57 & 13 & 42 \\
$\begin{array}{l}\text { Anti-GAD65 antibodies } \\
\text { (normalized OD units) }\end{array}$ & $0.024 \pm 0.003^{*}$ & $0.038 \pm 0.005$ & $0.004 \pm .0020$ \\
$\begin{array}{l}\text { Anti-insulin antibodies } \\
\text { (normalized OD units) }\end{array}$ & $0.033 \pm 0.023^{*}$ & $0.045 \pm 0.007$ & $0.0037 \pm 0.0019$ \\
$\begin{array}{l}\text { Anti-TP antibodies } \\
\text { (normalized OD units) }\end{array}$ & $0.014 \pm 0.003^{\circledR}$ & $0.019 \pm 0.001$ & $0.0035 \pm 0.0021$ \\
\hline
\end{tabular}

Abbreviations: T1D, type 1 diabetes; GAD65, glutamic acid decarboxylase; TP, tyrosine phosphate; $n$, number of serum samples tested, SEM, standard error of means. $\# p<0.01$ versus anti-GAD65 antibodies present in T1D neuropathy patients; ${ }^{*} \mathrm{p}<0.01$ versus anti-insulin antibodies detected in T1D neuropathy patients; ${ }^{\circledR} \mathrm{p}<0.05$ versus anti-TP antibodies detected T1D neuropathy patients.

Anti-insulin autoantibodies in Type 1 diabetes patients Sera from 57 diabetes patients and 42 normal human subjects were screened for the detection of anti-insulin antibodies (IAA). Our results showed that 76\% T1D patient's sera showed strong binding human insulin at 1:100 serum dilutions (Table 3). To validate our hypothesis, we assessed the increases in serum levels of IAA antibodies as a function of the disease activity. As evident in Figure 2a, levels of IAA in diabetes patients (both those with age $\leq 35$ years and those with age $>35$ ) were significantly higher in comparison with healthy controls $(p<0.0001)$. Interestingly, levels of IAA antibodies in diabetes patients with age $>35$ years were significantly higher than those age $\leq 35$ years $(p<0.001)$. Our results also showed that autoantibodies against human insulin increase with the patient's age (Table 2). In addition, remarkably increased levels of IAA antibodies in patients with higher $\mathrm{HbA}_{1 \mathrm{C}}$ (Figure $\mathbf{2 b}$ ) in comparison with those in patients with lower $\mathrm{HbA}_{1 C^{\prime}}$ suggest a positive association between the increase in IAA and disease activity. Our results also showed that (a)

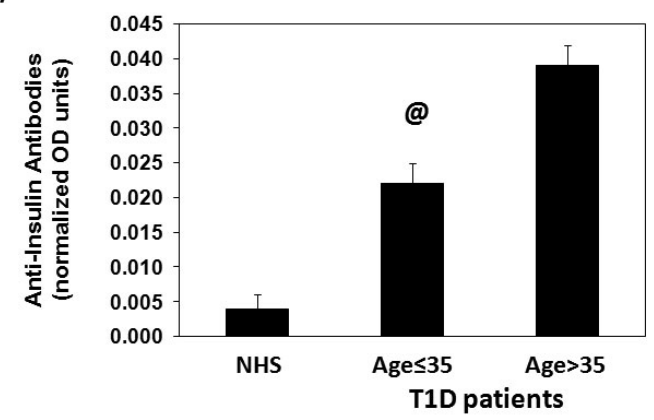

(b)

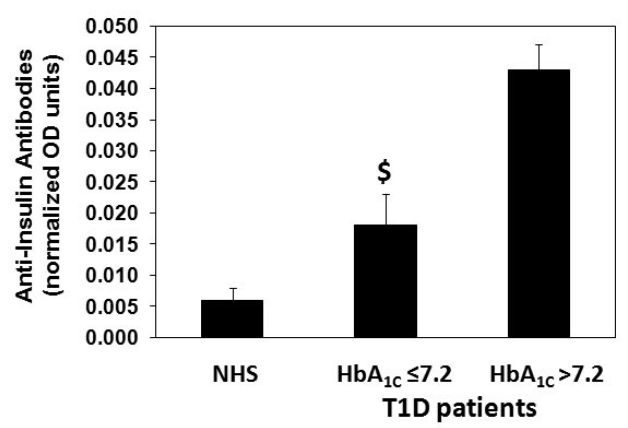

Figure 2. Detection of ant-insulin antibodies (IAA) in type 1 diabetes patients.

(a) Age-wise detection of IAA in type 1 diabetes (T1D) patients. ${ }^{\circledR} \mathrm{p}<0.001$ versus IAA detected in T1D patients of age $>35 ;{ }^{\circledR} \mathrm{p}<0.0001$ versus IAA detected in normal human subjects (NHS).

(b) Glycosylated hemoglobin (HbA1C)-wise detection of IAA in T1D patients. ${ }^{\$} \mathrm{p}<0.0001$ versus IAA detected in T1D patients with $\mathrm{HbA} 1 \mathrm{C}>7.2 ;{ }^{\$} \mathrm{p}<0.001$ versus IAA detected in NHS. The number of T1D serum samples was 57 and NHS was 42 . Insulin-specific direct binding ELISAs were used and serum samples were 1:100 diluted. Results show mean with 95\%CI.

levels of IAA were higher in diabetic neuropathy patients as compared to those patients which were not having any secondary complications (Table 3 ). 


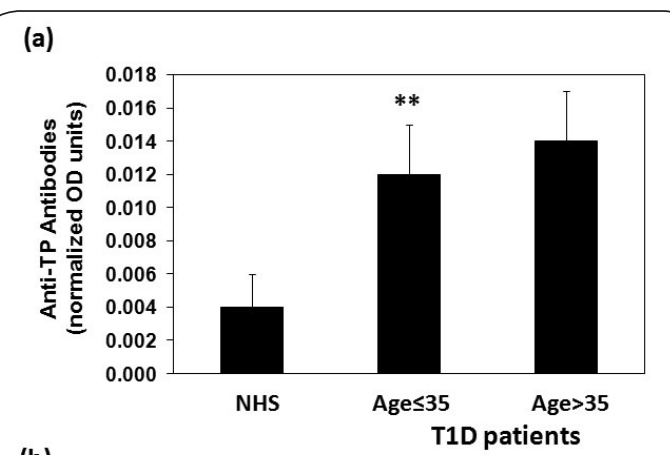

(b)

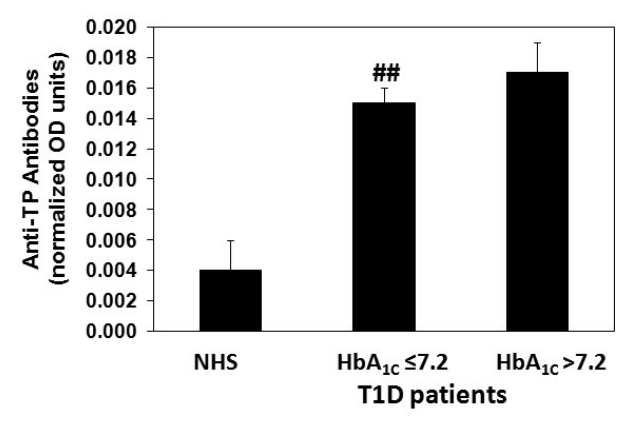

Figure 3. Detection of anti-tyrosine phosphatase (TP) antibodies in type 1 diabetes patients. (a) Age-wise detection of anti-TP antibodies in type 1 diabetes (T1D) patients. ${ }^{* *} \mathrm{p}>0.05$ versus anti$\mathrm{TP}$ antibodies detected in T1D patients of age $>35$; ${ }^{* *} \mathrm{p}<0.0001$ versus anti-TP antibodies detected in normal human subjects (NHS). (b) Glycosylated hemoglobin (HbAlC)-wise detection of anti$\mathrm{TP}$ antibodies in T1D patients. \#\# $\mathrm{p}<0.05$ versus anti-TP antibodies detected in T1D patients with HbA1C $>7.2$; \#\# $<0.0001$ versus anti-TP antibodies detected in NHS. Thenumber of T1D serum samples was 57 and NHS was 42. TP-specific sandwich ELISAs were used and serum samples were 1:100 diluted. Results show mean with 95\%CI.

Levels of anti-tyrosine phosphatase autoantibodies in patients with type 1 diabetes

Sera from 57 diabetes patients and 42 normal human subjects were screened for the detection of anti-tyrosine phosphatase (TP) antibodies by TP-specific sandwich ELISAs. Our data showed that 34\% T1D patients' sera showed strong binding human insulin at 1:100 serum dilutions. Figure 3a shows that the levels of anti-TP-antibodies in all tested diabetes patients (both those with age $\leq 35$ years and those with age $>35$ ) were significantly higher in comparison with healthy controls $(p<0.001)$. In contrast to our central hypothesis that levels of anti-TP-antibodies in diabetes patients with age $>35$ years were higher than those age $\leq 35$ years, but this difference in the occurrence of anti-TPantibodies in these groups was not statistically significant ( $p>0.05$ ) (Figure 1a). Not only this, we also determined the levels of anti-TP autoantibodies in different age groups, our results showed that autoantibodies against tyrosine phosphatase increase with the patient's age and the levels

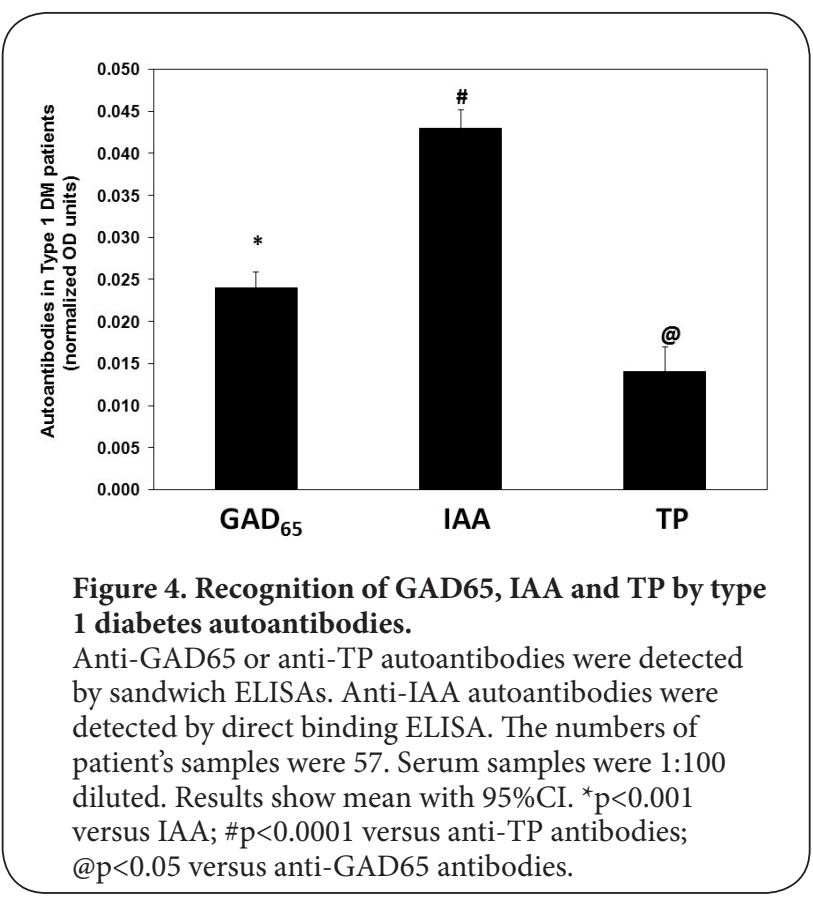

of these autoantibodies were saturated after 60 years of patients age (Table 2). Furthermore, levels of serum antiTP-antibodies were increased with the increased of $\mathrm{HbA}_{1 C}$ (Figure $\mathbf{3 b}$ ). In addition, we also determined that levels of anti-TP antibodies in T1D neuropathic patients were found to be higher as compared with patients without neuropathy $(p<0.05$; Table 3$)$.

Comparative assessment of anti-GAD ${ }_{65}$-antibodies, anti-insulin-antibodies and anti-TP-antibodies in patients with type 1 diabetes

The occurrence of antibodies against $\mathrm{GAD}_{65}$, insulin and tyrosine phosphatase in type 1 diabetes patients has been shown in Figure 4. Our novel data showed that 42\% T1D patient's sera showed strong binding with $\mathrm{GAD}_{65}, 76 \%$ T1D patient's sera showed strong binding with human insulin, whereas $34 \%$ of patient's sera strongly recognized tyrosine phospatase.

\section{Discussion}

Type 1 diabetes (T1D) is a chronic autoimmune disease in which insulin-producing $\beta$-cells are located in the pancreatic islets of Langerhans, which are gradually destroyed by autoreactive T cells $[2,3,9]$. Prospective studies with pre-T1D patients have shown that the process of $\beta$-cell degeneration can take more than 3 years before the clinical manifestation and the disease progression occurs in waves or in cycles [24]. Despite the power of modern molecular and immunological approaches and persisting investigative efforts, T1D remains an enigmatic disorder and the agent (or agents) triggering this autoimmune disorder remains to be identified $[\mathbf{2 5}, \mathbf{2 6}]$. Current understanding of 
the aetiology and pathogenesis of T1D show that disease most likely results from an unfortunate combination of genetic susceptibility and exposure to an environmental trigger $[\mathbf{2 7}, \mathbf{2 8}]$. The main effector mechanism is clearly an autoimmune reaction, which is also evident at time of clinical diagnosis. This implies two concepts for clinical treatment: the first one is the knowledge of the cause is more critical for prevention than for at-onset therapy, and the other is at/near-onset therapy requires an immune silencing $[2,10,11]$. All these debates clearly indicate that several silent immune events occur before the appearance of clinical symptoms in T1D, which strongly suggest that immunological events play a fundamental role in the onset as well as in the progression of T1D. In view of these, we believe that the factors responsible for T1D include the appearance and spreading of antigenic determinants. The speed of T1D progression could depend on the degree of epitope spreading, which is an intrinsic to the immunological process that leads to T1D [29]. If the regulatory response is insufficient, the recurring immune events could eventually lead to the destruction of the majority of the islet $\beta$-cell mass and thereby reduce the body's capacity to produce insulin [30-32]. Understanding and mapping the precise kinetics of the immune response to the disease has implications for the design of immunomodulatory therapeutics, and the regulatory immune components of T1D could be therapeutically exploited to ultimately suppress the progression of T1D [33-35]. However, the temporal and compositional details of the immune regulation that are associated with the onset and progress of T1D remain controversial $[2,36]$.

Autoantibodies are currently the most robust biomarkers of T1D and are frequently used to establish entry criteria for the participation of genetically at-risk individuals in secondary prevention/intervention clinical trials. Since their original description almost 40 years ago, considerable efforts have been devoted toward identifying the precise molecular targets that are recognized. Such information can have significant benefit for developing improved metrics for identifying/stratifying of at-risk subjects, developing potential therapeutic targets, and advancing understanding of the pathophysiology of the disease [27]. Currently, three major molecular targets (insulin, $\mathrm{GAD}_{65}$ and IA-2) have been reported, with approximately $94 \%$ of all subjects with a clinical diagnosis of T1D expressing autoantibodies to at least one of these molecules at clinical onset [2,3,9-11]. However, the precise interrelation of these markers autoantibodies with the extent of T1D progress is largely unknown. Therefore, in the present study we have investigated the levels of autoantibodies against $\mathrm{GAD}_{65}$, IA-2A and IAA in T1D patients and to explore whether these markers autoantibodies have a role in disease induction and progression. Our data demonstrate that 42\% T1D patient's serum autoantibodies showed strong binding with $\mathrm{GAD}_{65}, 76 \%$ T1D patient's autoantibodies showed binding with human insulin, whereas 34\% autoantibodies from patient's showed recognition of tyrosine phosphatase. This clearly indicated that autoimmunity against insulin is much stronger than $\mathrm{GAD}_{65}$ or tyrosine phosphatase. For the validation of our central hypothesis, we assessed the increases in serum levels of anti-GAD 65 antibodies, IA-2A and IAA as a function of the disease activity in different T1D patients groups. Analysis of Age-wise distribution anti-GAD 65 antibodies, IAA or IA-2A show that levels of anti-GAD ${ }_{65}$ antibodies, IAA or IA-2A in T1D patients with age $>35$ years were significantly higher than those age $\leq 35$ years. This indicating that age plays a role in the occurrence of these markers autoantibodies. $\mathrm{HbA}_{1 \mathrm{c}}$ wise distribution of autoantibodies show high levels of anti-GAD ${ }_{65}$ antibodies, IAA or IA-2A in patients with higher $\mathrm{HbA}_{1 \mathrm{C}}$ in comparison with those in patients with lower $\mathrm{HbA}_{1 \mathrm{C}}$, suggesting a positive association between the increase in anti-GAD ${ }_{65}$ antibodies, IAA or IA-2A and disease progress.

The prevalence of T1D associated secondary complications is rapidly increasing worldwide [37], but the treatment of such complications is limited. Diabetic neuropathy represents its major complication with multiple clinical manifestations, which is detected in up to $57 \%$ of T1D patients $[38,39]$. The pathogenesis of diabetic neuropathy is still not fully understood and may involve multiple mechanisms. In the literature, controversial data regarding the association markers autoantibodies and diabetic neuropathy have been reported $[12,19-21,40]$. To verify whether autoimmune markers of T1D are associated with subclinical neuropathy, we examined the levels of anti-GAD ${ }_{65}$ antibodies, IAA and IA-2A in T1D neuropathic patients. Our data show that these autoantibodies were found to be higher in diabetic neuropathy patients as compared to non-neuropathic T1D patients. These data clearly pointed out that these autoantibodies not only play a role in autoimmune diabetes, but also in autoimmune diabetic neuropathy.

\section{Conclusions}

This is the first study that compares the levels of occurrence of autoantibodies against $\mathrm{GAD}_{65}$, insulin and tyrosine phosphatase in type 1 diabetes patients. Our results demonstrate the role of anti-GAD 65 antibodies, anti-insulin antibodies and anti-tyrosine phosphatise antibodies in type 1 diabetes and in diabetic neuropathy, which might play an active part in the progression of disease. Our findings support an association between these autoantibodies and type 1 diabetes. The stronger response observed in serum samples from patients with higher age and higher $\mathrm{HbA}_{1 \mathrm{c}}$ scores suggests that these autoantibodies may be useful in evaluating the progression of type 1 diabetes and in elucidating the mechanisms of disease pathogenesis.

\section{Competing interests}

The authors declare that they have no competing interests. 
Farhan et al. Journal of Diabetes Research \& Clinical Metabolism 2013, http://www.hoajonline.com/journals/pdf/2050-0866-2-24.pdf

\section{Authors' contributions}

\begin{tabular}{|l|c|c|c|c|c|}
\hline Authors' contributions & JF & AA & UZ & AMAM & ZR \\
\hline Research concept and design & $\sqrt{ }$ & $\sqrt{ }$ & -- & -- & $\sqrt{ }$ \\
\hline Collection and/or assembly of data & $\sqrt{ }$ & -- & $\sqrt{ }$ & $\sqrt{ }$ & $\sqrt{ }$ \\
\hline Data analysis and interpretation & $\sqrt{ }$ & & $\sqrt{ }$ & $\sqrt{ }$ & $\sqrt{ }$ \\
\hline Writing the article & $\sqrt{ }$ & $\sqrt{ }$ & $\sqrt{ }$ & -- & $\sqrt{ }$ \\
\hline Critical revision of the article & $\sqrt{ }$ & $\sqrt{ }$ & -- & -- & $\sqrt{ }$ \\
\hline Final approval of article & $\sqrt{ }$ & $\sqrt{ }$ & $\sqrt{ }$ & $\sqrt{ }$ & $\sqrt{ }$ \\
\hline Statistical analysis & -- & -- & -- & $\sqrt{ }$ & $\sqrt{ }$ \\
\hline
\end{tabular}

\section{Acknowledgement}

This work was fully funded by Qassim University

Research Deanship Grant SR-D-011-1022.

Publication history

Editor: Pere Santamaria, University of Calgary, Canada.

Received: 22-Jun-2013 Revised: 19-Sep-2013

Accepted: 27-Sep-2013 Published: 07-Oct-2013

\section{References}

1. Baumann B, Salem HH and Boehm BO. Anti-inflammatory therapy in type 1 diabetes. Curr Diab Rep. 2012; 12:499-509. | Article | PubMed

2. Lernmark $A$ and Larsson HE. Immune therapy in type 1 diabetes mellitus. Nat Rev Endocrinol. 2013; 9:92-103. | Article | PubMed

3. Pihoker C, Gilliam LK, Hampe CS and Lernmark A. Autoantibodies in diabetes. Diabetes. 2005; 54 Suppl 2:S52-61. | Article | PubMed

4. Steck AK and Rewers MJ. Genetics of type 1 diabetes. Clin Chem. 2011; 57:176-85. | Article | PubMed

5. Calsolari MR, Rosario PW, Reis JS, Silva SC and Purisch S. [Latent autoimmune diabetes of adult or slim type $\mathbf{2}$ diabetes mellitus?]. Arq Bras Endocrinol Metabol. 2008; 52:315-21. | Article | PubMed

6. Bingley PJ. Clinical applications of diabetes antibody testing. J Clin Endocrinol Metab. 2010; 95:25-33. | Article | PubMed

7. Lernmark $A$ and Agardh $C D$. Immunomodulation with human recombinant autoantigens. Trends Immunol. 2005; 26:608-12. | Article | PubMed

8. Seissler J, Hatziagelaki E and Scherbaum WA. Modern concepts for the prediction of type 1 diabetes. Exp Clin Endocrinol Diabetes. 2001; 109 Suppl 2:S304-16. | Article | PubMed

9. Schmidt KD, Valeri $C$ and Leslie RD. Autoantibodies in Type 1 diabetes. Clin Chim Acta. 2005; 354:35-40. | Article | PubMed

10. Miao D, Yu L and Eisenbarth GS. Role of autoantibodies in type 1 diabetes. Front Biosci. 2007; 12:1889-98. | Pdf | PubMed

11. Pozzilli P, Manfrini S and Monetini L. Biochemical markers of type 1 diabetes: clinical use. Scand J Clin Lab Invest Suppl. 2001; 235:38-44. | Article | PubMed

12. Lucchetta M, Rudilosso $S$, Costa $S$, Bruttomesso D, Ruggero $S$, Toffanin E, Faggian D, Plebani M, Battistin L, Alaedini A and Briani C. Antiganglioside autoantibodies in type 1 diabetes. Muscle Nerve. 2010; 41:50-3. | Article | PubMed

13. Duchen LW, Anjorin A, Watkins PJ and Mackay JD. Pathology of autonomic neuropathy in diabetes mellitus. Ann Intern Med. 1980; 92:301-3. | Article | PubMed

14. Gilbey SG, Hussain MJ, Watkins PJ and Vergani D. Cell-mediated immunity and symptomatic diabetic autonomic neuropathy. Diabet Med. 1988; 5:845-8. | Article | PubMed

15. Gilbey SG, Guy RJ, Jones H, Vergani D and Watkins PJ. Diabetes and autonomic neuropathy: an immunological association? Diabet Med. 1986; 3:241-5. | Article | PubMed

16. Zanone MM, Peakman M, Purewal T, Watkins PJ and Vergani D. Autoantibodies to nervous tissue structures are associated with autonomic neuropathy in type 1 (insulin-dependent) diabetes mellitus. Diabetologia. 1993; 36:564-9. | Article | PubMed

17. Rabinowe SL. Immunology of diabetic and polyglandular neuropathy. Diabetes Metab Rev. 1990; 6:169-88. | Article | PubMed

18. Rabinowe SL, Brown FM, Watts M and Smith AM. Complement-fixing antibodies to sympathetic and parasympathetic tissues in IDDM. Autonomic brake index and heart-rate variation. Diabetes Care. 1990; 13:1084-8. | Article | PubMed

19. Kaufman DL, Erlander MG, Clare-Salzler M, Atkinson MA, Maclaren NK and Tobin AJ. Autoimmunity to two forms of glutamate decarboxylase in insulin-dependent diabetes mellitus. J Clin Invest. 1992; 89:283-92. | Article | PubMed Abstract | PubMed Full Text

20. Ortqvist E, Brooks-Worrell B, Lynch K, Radtke J, Bekris LM, Kockum I, Agardh CD, Cilio CM, Lethagen AL, Persson B, Lernmark A, Reichow J, Oak S, Palmer JP and Hampe CS. Changes in GAD65Ab-specific antiidiotypic antibody levels correlate with changes in C-peptide levels and progression to islet cell autoimmunity. $J$ Clin Endocrinol Metab. 2010; 95:E310-8. | Article | PubMed Abstract | PubMed Full $\underline{\text { Text }}$

21. Morano S, Tiberti C, Cristina G, Sensi M, Cipriani R, Guidobaldi L, Torresi P, Medici F, Anastasi E and Di Mario U. Autoimmune markers and neurological complications in non-insulin-dependent diabetes mellitus. Hum Immunol. 1999; 60:848-54. | Article | PubMed

22. Al-Shobaili HA, Al Robaee AA, Alzolibani AA and Rasheed Z. Antibodies against 4-hydroxy-2-nonenal modified epitopes recognized chromatin and its oxidized forms: role of chromatin, oxidized forms of chromatin and 4-hydroxy-2-nonenal modified epitopes in the etiopathogenesis of SLE. Dis Markers. 2012; 33:19-34. | Article | PubMed

23. Ryden L, Standl E, Bartnik M, Van den Berghe G, Betteridge J, de Boer MJ, Cosentino F, Jonsson B, Laakso M, Malmberg K et al. Guidelines on diabetes, pre-diabetes, and cardiovascular diseases: executive summary. The Task Force on Diabetes and Cardiovascular Diseases of the European Society of Cardiology (ESC) and of the European Association for the Study of Diabetes (EASD). Eur Heart J. 2007; 28:88-136. | Article | PubMed

24. Rodriguez-Segade S, Camina MF, Carnero A, Lorenzo MJ, Alban A, Quinteiro $C$ and Lojo $S$. High serum IgA concentrations in patients with diabetes mellitus: agewise distribution and relation to chronic complications. Clin Chem. 1996; 42:1064-7. | Article | PubMed

25. Thrower SL and Bingley PJ. Prevention of type 1 diabetes. Br Med Bull. 2011; 99:73-88. | Article | PubMed

26. Dahlquist $G$. The aetiology of type 1 diabetes: an epidemiological perspective. Acta Paediatr Suppl. 1998; 425:5-10. | Article | PubMed

27. Wenzlau JM and Hutton JC. Novel diabetes autoantibodies and prediction of type 1 diabetes. Curr Diab Rep. 2013; 13:608-15. | Article | PubMed

28. Phlips JC and Radermecker RP. [Type 1 diabetes: from genetic predisposition to hypothetical environmental triggers]. Rev Med Liege. 2012; 67:319-25. | PubMed

29. Casares $S$ and Brumeanu TD. Insights into the pathogenesis of type 1 diabetes: a hint for novel immunospecific therapies. Curr Mol Med. 2001; 1:357-78. | Article | PubMed

30. Lightfoot YL, Chen J and Mathews CE. Immune-mediated beta-cell death in type 1 diabetes: lessons from human beta-cell lines. Eur J Clin Invest. 2012; 42:1244-51. | Article | PubMed Abstract | PubMed Full Text

31. Gallagher MP, Goland RS and Greenbaum CJ. Making progress: preserving beta cells in type 1 diabetes. Ann N Y Acad Sci. 2011 1243:119-34. | Article | PubMed

32. Keymeulen B. New therapies aimed at the preservation or restoration of beta cell function in type 1 diabetes. Acta Clin Belg. 2006; 61:275-85. | Article | PubMed

33. Hober D, Sane F, Jaidane H, Riedweg K, Goffard A and Desailloud R. Immunology in the clinic review series; focus on type 1 diabetes and viruses: role of antibodies enhancing the infection with Coxsackievirus- $B$ in the pathogenesis of type 1 diabetes. Clin Exp Immunol. 2012; 168:47-51. | Article | PubMed Abstract | PubMed 
Farhan et al. Journal of Diabetes Research \& Clinical Metabolism 2013, http://www.hoajonline.com/journals/pdf/2050-0866-2-24.pdf

Full Text

34. Li L, Yi Z, Tisch R and Wang B. Immunotherapy of type 1 diabetes. Arch Immunol Ther Exp (Warsz). 2008; 56:227-36. | Article | PubMed

35. Goudy KS and Tisch R. Immunotherapy for the prevention and treatment of type 1 diabetes. Int Rev Immunol. 2005; 24:307-26. I Article I PubMed

36. Jin $Y$ and She JX. Novel biomarkers in type 1 diabetes. Rev Diabet Stud. 2012; 9:224-35. I Article | PubMed

37. Knip M. Descriptive epidemiology of type 1 diabetes--is it still in? Diabetologia. 2012; 55:1227-30. | Article | PubMed

38. Callaghan BC, Hur J and Feldman EL. Diabetic neuropathy: one disease or two? Curr Opin Neurol. 2012; 25:536-41. | Article | PubMed

39. Callaghan BC, Cheng HT, Stables CL, Smith AL and Feldman EL. Diabetic neuropathy: clinical manifestations and current treatments. Lancet Neurol. 2012; 11:521-34. | Article | PubMed

40. Muhr D, Mollenhauer U, Ziegler AG, Haslbeck M, Standl E and Schnell O. Autoantibodies to sympathetic ganglia, GAD, or tyrosine phosphatase in long-term IDDM with and without ECG-based cardiac autonomic neuropathy. Diabetes Care. 1997; 20:1009-12. I Article | PubMed

\section{Citation:}

Farhan J, Alghasham A, Zafar U, Meki A-RMA

and Rasheed Z. Impact of anti-glutamic acid decarboxylase-65, anti-insulin and anti-tyrosine phosphatase autoantibodies on disease activity in type 1 diabetes patients. J Diab Res Clin Met. 2013; 2:24.

http://dx.doi.org/10.7243/2050-0866-2-24 